\title{
GESTÃO DE RECURSOS HÍDRICOS NO RIO GRANDE DO NORTE: UMA ANÁLISE DA IMPLEMENTAÇÃO DA POLÍTICA HÍDRICA
}

\author{
M. A. Oliveira'; E. M. Barbosa ${ }^{2}$ e J. Dantas Neto
${ }^{3}$
'Doutorando do Programa de Recursos Naturais - Universidade Federal de Campina Grande (UFCG/PPGRN)
${ }^{2}$ Professor Adjunto - Universidade Federal de Campina Grande (UFCG/PPGRN)
${ }^{3}$ Professor Associado - Universidade Federal de Campina Grande (UFCG/PPGRN)
marcos.oliveira@ifrn.edu.br' ${ }^{1}$; erifat@terra.com.br ${ }^{2}$ e zedantas@deag.ufcg.edu.br
}

Artigo submetido em dezembro/2012 e aceito em fevereiro/2013

\section{RESUMO}

O estudo analisa as medidas adotadas pelo poder público estadual para a implantação de um novo modelo de gestão hídrica, o modelo sistêmico, introduzido pela política nacional de recursos hídricos. O objetivo principal é analisar o processo de implementação desse novo modelo no âmbito do estado do Rio Grande do Norte, a partir da sistematização dos mecanismos gerenciais em funcionamento e à luz da legislação vigente. A abordagem é fruto de uma pesquisa exploratória realizada a partir de documentos impressos e eletrônicos e em ampla legislação federal e estadual sobre a matéria. Os aspectos mais relevantes para a compreensão da temática são os aspectos legais, nas esferas federal e estadual, a (re) estruturação dos órgãos públicos estaduais que atuam na gestão das águas e a organização dos comitês de bacias hidrográficas. Constata-se que a gestão hídrica estadual apresenta fortes traços do modelo econômicofinanceiro, baseado em planejamento estratégico, instrumentos econômicos e tecnocracia. Não obstante, o arcabouço normativo e as iniciativas do estado, embora marcadas pela morosidade, indicam a possibilidade de mudança para o modelo sistêmico, fundado na gestão democrática, participativa e deliberativa.

\section{WATER MANAGEMENT IN RIO GRANDE DO NORTE: A REVIEW OF THE IMPLEMENTATION OF WATER POLICY}

\begin{abstract}
The study examines the measures adopted by the state government to roll out a new model of water management, the systemic model, introduced by the national water policy. The main objective is to analyze the process of implementing this new model in the state of Rio Grande do Norte, from the systematization of operation and management mechanisms in the light of current legislation. The approach is the result of a survey carried out from paper and electronic documents and extensive federal and state legislation on the subject. The most relevant for the understanding of the theme is
\end{abstract}

the legal, the federal and state level, the (re) structuring of state agencies working on water management and organization of river basin committees. It appears that the state water management shows strong traces of economic-financial model based on strategic planning, economic instruments and technocracy. Nevertheless, the normative framework and the initiatives of the state, although marked by slowness, indicate the possibility of change for the systemic model, founded on democratic, participatory and deliberative.

KEY-WORDS: Water Resources Management, Water Policy, Watershed Committees. 


\section{GESTÃO DE RECURSOS HÍDRICOS NO RIO GRANDE DO NORTE: UMA ANÁLISE DA IMPLEMENTAÇÃO DA POLÍTICA HÍDRICA}

\section{INTRODUÇÃO}

O Rio Grande do Norte, a partir de meados dos anos 1990, realiza investimentos em programas de captação, armazenamento, tratamento e distribuição de recursos hídricos, a fim de garantir o abastecimento das populações e o desenvolvimento das atividades econômicas. A construção de reservatórios, canais, poços e um dos maiores sistemas adutores do país ainda não fora suficiente para superar o problema do abastecimento.

A questão do abastecimento não se limita à quantidade de água disponibilizada, conforme preconizam muitos estudos sobre as demandas do setor hídrico. Qualidade da água, redução do elevado índice de desperdício, democratização do acesso, cobrança pelo uso da água, manutenção das matas ciliares e nascentes, redução da poluição a níveis aceitáveis e aporte de investimentos em educação ambiental, pesquisa, obras de manutenção e ampliação dos sistemas de abastecimento são dimensões tão importantes quanto a quantidade desse recurso.

A Lei no 9.433/1997, que cria a Política Nacional de Recursos Hídricos, instituiu um novo modelo de gestão das águas, baseado nos princípios da descentralização e da participação. Na sistemática do Código de Águas de 1934, que antecedeu à citada lei, as decisões eram prerrogativas exclusivas do poder público. No novo sistema, a descentralização possibilita a inclusão de usuários e sociedade civil que, juntos com os entes estatais (União, EstadosMembros, Distrito Federal e Municípios), formam a tríade responsável pelo gerenciamento das águas no Brasil.

A lei hídrica federal, conhecida como lei das águas, inovou no sentido de estabelecer as bases e os princípios para uma gestão democrática dos recursos hídricos. Contudo, a efetividade destes princípios exige uma atuação qualificada dos órgãos dos sistemas de gerenciamento de recursos hídricos no âmbito da federação, dentre os quais assumem especial relevância os comitês de bacias hidrográficas (CBHs), instâncias de planejamento, decisão e implementação da política hídrica.

A lei das águas garantiu ao segmento dos usuários (detentores da outorga do direito de uso das águas) $40 \%$ da representatividade nos comitês federais, o que denota o caráter regulatório do sistema de gestão, haja vista que as negociações são estabelecidas tendo como foco os usuários da água e não o poder público.

A Lei Estadual no 6.908/1996, que instituiu a Política Estadual de Recursos Hídricos e o Sistema Integrado de Gestão de Recursos Hídricos (SIGERH), entrou em vigor antes da lei das águas, recepcionou os princípios da Carta Magna de 1988 e concebeu o sistema de gestão hídrica com base na gestão participativa e descentralizada, na bacia hidrográfica como unidade de gestão e na implementação de instrumentos econômicos de gestão, com ênfase na cobrança pelo uso da água e criação do Fundo Estadual de Recursos Hídricos (FUNERH).

Do exposto, questiona-se:

I. A antecipação da promulgação da lei hídrica estadual em relação à federal teria contribuído para o avanço da gestão estadual das águas?

II. De que modo o estado vem se organizando para a implementação de uma gestão participativa e descentralizada das águas? 
III. Quais são os principais avanços e limitações nessa perspectiva?

IV. Em que condições de funcionamento se encontram os órgãos do SIGERH?

V. Quais os instrumentos de gestão implantados e em implantação?

VI. Que resultados já foram obtidos?

VII. Quais as fontes de financiamento da política estadual de recursos hídricos?

Esses questionamentos motivaram a sistematização da produção normativa e dos mecanismos gerenciais em funcionamento que se constituem no eixo central para a compreensão da gestão dos recursos hídricos no Rio Grande do Norte.

\section{MATERIAIS E MÉTODOS}

O estudo foi desenvolvido em 2012 e teve como recorte espacial o território do Rio Grande do Norte, com ênfase nos municípios que apresentam algum tipo de mobilização social para constituição de organismos de gestão das águas. A população do estudo é constituída pelo arranjo institucional e pelos atores sociais da gestão dos recursos hídricos do estado, de modo a contemplar todas as suas representações (poder público, usuários de água e sociedade civil).

A pesquisa é do tipo exploratória e se fundamenta em referencial teórico amplo e atual, documentos impressos e eletrônicos e na legislação federal e estadual sobre as políticas hídricas nacional e do estado do Rio Grande do Norte. A pesquisa possibilitou evidenciar os aspectos mais relevantes para a compreensão da gestão hídrica estadual, quais sejam os aspectos legais nas esferas federal e estadual, a (re)estruturação dos órgãos públicos estaduais com interesse na gestão dos recursos hídricos e a organização de associações de usuários, comissões de usuários e comitês de bacia hidrográfica.

\section{MARCOS REGULATÓRIOS DA GESTÃO DOS RECURSOS HÍDRICOS DO RIO GRANDE DO NORTE}

Os marcos regulatórios referentes ao uso da água no Brasil são a Constituição Federal de 1988, a Lei no 9.433/1997 que instituiu a Política Nacional dos Recursos Hídricos e o Decreto № 24.643/1934, conhecido como Código de Águas.

O Código de Águas já assegurava o uso gratuito de qualquer corrente ou nascente de água para as primeiras necessidades da vida e permitia a todos o uso de quaisquer águas públicas, em conformidade com os regulamentos administrativos. A derivação das águas públicas para os usos agrícola, industrial e higiene estava vinculada à celebração dos instrumentos jurídicos da concessão, no caso de utilidade pública, e da autorização nos demais casos. Em qualquer hipótese, a preferência de derivação era concedida para o abastecimento das populações.

No Rio Grande do Norte, a exemplo do que ocorreu em outros 16 Estados-Membros da Federação, a publicação da Lei no 6.908/96, que trata do gerenciamento de recursos hídricos, ocorreu antes da promulgação da Lei no 9.433/97, que instituiu o Sistema Nacional de Gerenciamento de Recursos Hídricos, devido a demora na tramitação do Projeto de Lei no 2.249, de 03 de dezembro de 1991, no âmbito do Congresso Nacional.

As outorgas para utilização das águas e as licenças para obras de oferta hídrica são regulamentadas pelo Decreto $\mathrm{n}$ - 13.283/97, do governo do estado. A norma estadual, afastandose das disposições do Código de Águas sobre outorgas para derivação, preconiza as modalidades: 
autorização de uso, de caráter unilateral, a título precário; concessão de uso, de caráter contratual, a título permanente; e concessão especial de uso coletivo, de caráter contratual, a título permanente, à Associação de Usuários de Água.

A lei norteriograndense, da mesma forma que a lei cearense, alcançando pessoas físicas e jurídicas, estabelece que, enquanto não forem conhecidas e seguramente dimensionadas as disponibilidades hídricas, serão outorgadas apenas autorizações de uso.

\section{MODELOS DE GERENCIAMENTO DOS RECURSOS HÍDRICOS}

Setti et al (2001, apud SOUSA JÚNIOR, 2004) sugerem a existência de três modelos de gestão aplicados aos recursos hídricos: o modelo burocrático; o modelo econômico-financeiro; e o modelo de integração participativa ou modelo sistêmico. Esses modelos reproduziriam as características dos sistemas político, econômico e social de cada época.

O Estado empreendedor que emerge nos anos 1930, após a crise financeira global, adota o modelo burocrático de gestão pública, que se caracteriza pela centralização no Estado e funcionamento através dos chamados instrumentos de comando e controle. O marco legal desse modelo no campo da gestão hídrica é o Código de Águas (1934) e sua vigência se prolongaria aos anos 1970.

A transição para o modelo econômico-financeiro ocorre na década de 1980, influenciada pela abertura democrática. Este modelo se caracteriza pelo planejamento estratégico, amplamente difundido pelos teóricos da administração e pela aplicação dos instrumentos econômicos; as decisões são tomadas, exclusivamente, com base nos conhecimentos técnicos (tecnocracia).

Os ideais liberais dos anos 1990 influenciaram o surgimento do modelo sistêmico. A principal característica do novo modelo é a descentralização. O planejamento estratégico cede lugar ao planejamento compartilhado, o que implica na participação e no comprometimento de todos com os resultados da organização e não somente dos chamados gestores do topo. Daí decorre outra importante característica, a gestão participativa, que resguarda o direito de participação da coletividade nas decisões sem prejuízo dos pareceres técnicos sobre a matéria em apreciação. O novo modelo manteve os instrumentos econômicos do modelo econômicofinanceiro, com o qual ainda coexiste.

\section{GESTÃO DE BACIAS HIDROGRÁFICAS}

A participação e a descentralização, princípios basilares da Política Nacional dos Recursos Hídricos, foram recepcionados pelo ordenamento jurídico pátrio da Convenção de Dublin sobre Água e Meio Ambiente (1992). Essa Convenção propôs o princípio da gestão integrada dos recursos hídricos, os usos múltiplos da água e sua valoração econômica e a gestão participativa, envolvendo os usuários, planejadores e políticos em todos os níveis. No seu artigo primeiro estabelece que "a gestão dos recursos hídricos, para ser efetiva, deve ser integrada e [precisa] considerar todos os aspectos físicos, sociais e econômicos". 
Além destes princípios, a gestão das águas no Brasil é norteada também por outros princípios como a gestão integrada, bacia hidrográfica como unidade de gestão e planejamento e reconhecimento do valor econômico da água.

Para Porto e Porto (2008), a questão central que deve nortear a gestão dos recursos hídricos é a integração dos vários aspectos que interferem no uso das águas e na sua proteção ambiental. Desse modo, "a bacia hidrográfica é o palco unitário de interação das águas com o meio físico, o meio biótico e o meio social, econômico e cultural". (YASSUDA, 1993, apud PORTO; PORTO, 2008, p. 43)

A literatura especializada apresenta diversas definições para bacia hidrográfica, dentre as quais se destaca a definição de Tucci (2002, apud FERREIRA; SILVA; WERNECK, 2008, p. 38), segundo a qual, bacia hidrográfica é a:

\footnotetext{
Área de captação natural da água da precipitação que faz convergir os escoamentos para um único ponto de saída, seu exutório; compõe-se basicamente de um conjunto de superfícies vertentes e de uma rede de drenagem formada por cursos d'água que confluem até resultar um leito único no exutório.
}

Magalhães Jr. (2010, apud FERREIRA; SILVA; WERNECK, 2008) pondera que a bacia hidrográfica como unidade de gestão e planejamento apresenta vantagens e desvantagens. A principal vantagem está na rede de drenagem de uma bacia consistir em um caminho preferencial na maior parte das relações causa-efeito, isto é, a bacia hidrográfica como um ente sistêmico. As desvantagens são que nem sempre os limites municipais e estaduais respeitam os divisores da bacia e, consequentemente, a dimensão espacial de algumas relações de causaefeito de caráter econômico e político o que é um potencial gerador de conflitos.

A questão dos conflitos entre usuários de recursos hídricos independe da divisão política do território, haja vista que "as atividades dos usuários de água são competitivas por natureza e se acirram à medida que diminui a disponibilidade hídrica per capita" (PORTO; PORTO, 2008, p. 49). A gestão desses conflitos deve ser feita em nível local através da atuação dos comitês de bacia, instituições concebidas pela lei das águas para implementação em nível de bacias ou subbacias hidrográficas.

\section{BACIAS HIDROGRÁFICAS DO RIO GRANDE DO NORTE}

O território potiguar é banhado por dezesseis bacias hidrográficas, sendo quatro delas de domínio federal - as bacias dos rios Piancó-Piranhas-Açu, Jacu, Curimataú e Guaju - responsáveis pela drenagem de $20.258,1 \mathrm{~km}^{2}$, equivalente a $38 \%$ do território potiguar. O volume total de águas superficiais dessas quatro bacias é de aproximadamente 3,296 bilhões de metros cúbicos, o que representa $67,5 \%$ das águas superficiais do estado. Nessa estatística não estão incluídas as águas federais dos reservatórios construídos em rios estaduais com recursos financeiros da União. (Quadro 1)

As águas federais presentes no estado estão concentradas, principalmente, na bacia do rio Piancó-Piranhas-Açu, que inclui as sub-bacias dos rios Espinharas e Seridó, nas bacias dos rios Curimataú, Jacu e Guaju e nos açudes públicos Engenheiro Armando Ribeiro Gonçalves, Bonito II, Flechas, Pau dos Ferros, Marcelino Vieira, Pilões, Riacho da Cruz II, Morcego, Mendubim, Alecrim, Sabugi, Itans, Cruzeta, Zangarelhas, Marechal Dutra, Dourado Poço Branco, Inharé, Trairí e Japi II. 


\section{Quadro 1: Disponibilidade Hídrica dos Recursos Superficiais no Rio Grande do Norte}

\begin{tabular}{|c|c|c|c|}
\hline \multicolumn{2}{|r|}{ Bacia Hidrográfica } & Área $\left(\mathrm{Km}^{2}\right)$ & Volume $\left(\mathrm{m}^{3}\right)$ \\
\hline 1 & Apodi-Mossoró & $14.276,0$ & 1.225 .833 .387 \\
\hline 2 & Piancó-Piranhas-Açu & $17.498,5$ & 3.275 .626 .573 \\
\hline 3 & Boqueirão & 250,5 & 11.074 .800 \\
\hline 4 & Punaú ${ }^{[*]}$ & 447,9 & --- \\
\hline 5 & Maxaranguape ${ }^{[*]}$ & 1010,2 & --- \\
\hline 6 & Ceará-Mirim & $2.635,7$ & 136.000 .000 \\
\hline 7 & Doce & 387,8 & 11.019 .525 \\
\hline 8 & Potengi & 1093,0 & 57.139 .587 \\
\hline 9 & Pirangi & 458,9 & 57.988 .750 \\
\hline 10 & Trairi $^{[*]}$ & $2.867,4$ & --- \\
\hline 11 & Jacu & $1.805,5$ & 20.649 .000 \\
\hline 12 & Catu $^{[*]}$ & 208,5 & --- \\
\hline 13 & Curimataú ${ }^{[*]}$ & 803,5 & --- \\
\hline 14 & Guaju $^{[*]}$ & 150,6 & --- \\
\hline 15 & Faixa Litorânea Norte de Escoamento Difuso ${ }^{[*]}$ & $5.736,4$ & --- \\
\hline 16 & Faixa Litorânea Leste de Escoamento Difuso & 649,4 & 84.268 .200 \\
\hline \multicolumn{2}{|c|}{ Totalização das área e volumes } & $53.306,8$ & 4.879 .599 .822 \\
\hline \multicolumn{4}{|c|}{$\begin{array}{l}\text { Fonte: Elaborado pelos autores, com base nos dados da Situação Volumétrica de } \\
\text { Reservatórios (SEMARH, 2012) }\end{array}$} \\
\hline
\end{tabular}

A constatação acima reforça a necessidade de planejamento dos órgãos estaduais responsáveis pela implementação das políticas federal e estadual de recursos hídricos para atuação nessas duas realidades distintas - bacias estaduais e federais - especialmente porque a aplicação dos princípios da participação e da descentralização em bacias federais apresentam maior nível de complexidade face à diversidade dos arranjos institucionais que englobam atores de outros unidades federativas.

\section{O SISTEMA INTEGRADO DE GERENCIAMENTO DOS RECURSOS HÍDRICOS DO RIO GRANDE DO NORTE}

O Sistema Integrado de Gerenciamento dos Recursos Hídricos do Rio Grande do Norte foi instituído pelo Decreto no 13.284/1997, que definiu os objetivos (art. 1ㅇ), a estrutura organizacional (art. 2ㅇ) e a forma de atuação do SIGERH, mediante "articulação coordenada dos órgãos e entidades que o constituem e a sociedade civil" (art. 3으).

A estrutura organizacional do SIGERH é composta por três órgãos: Conselho Estadual de Recursos Hídricos (CONERH), Secretaria de Estado do Meio Ambiente e dos Recursos Hídricos (SEMARH) e Comitês de Bacia Hidrográfica. O organograma do SIGERH, representado na figura 1, sistematiza a disposição dos órgãos que o constitui e mostra suas inter-relações.

A Secretaria de Estado do Meio Ambiente e dos Recursos Hídricos é o órgão central do SIGERH e responsável pelo gerenciamento da política hídrica estadual (órgão gestor). A SEMARH resultou da transformação da antiga Secretaria de Estado dos Recursos Hídricos (SERHID) por força da Lei Complementar no 340, de 31 de janeiro de 2007. 
Figura 1 - Sistema Integrado de Gerenciamento dos Recursos Hídricos do Rio Grande do Norte

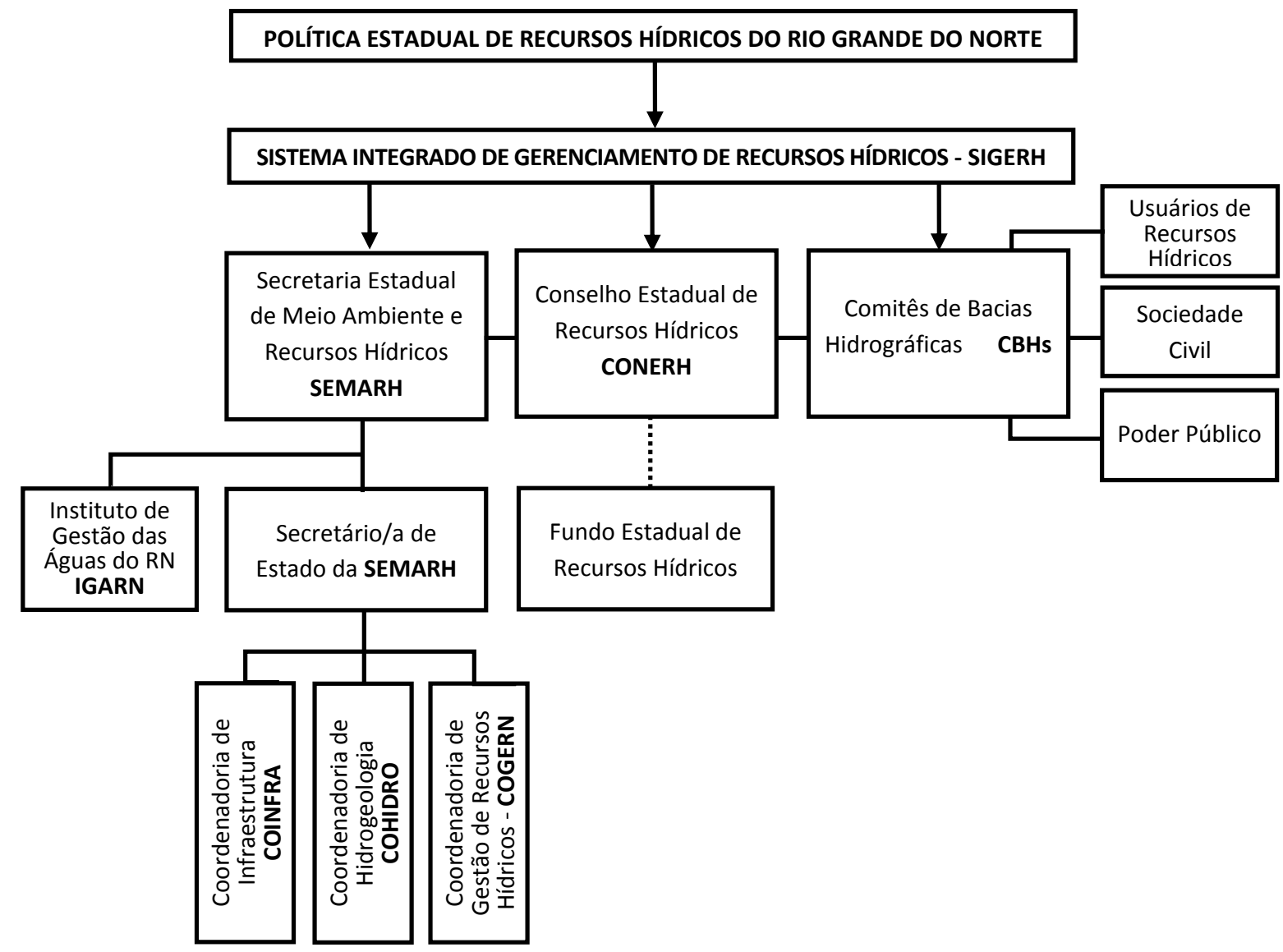

Fonte:Elaborado pelos autores, com base Lei no 6.908/1996 e no Decreto № 13.284/2007

As competências da SEMARH encontram-se no art. 23, incisos I a XVIII, da Lei no 6.908/1996. Destacam-se a formulação de políticas e diretrizes para o gerenciamento dos recursos hídricos e a elaboração e atualização do plano estadual de recursos hídricos (PERH). A lei atribuiu-Ihe também funções de natureza executiva, tais como: estudos de engenharia; análise e parecer sobre outorgas; análise de projetos; concessão de licenças; operação de estações; cobrança pelo uso da água; aplicação de multas; implantação e manutenção de banco de dados sobre os recursos hídricos; e exercício do poder de polícia administrativa, dentre outras.

A Lei Complementar no 340, no seu art. 35, acrescenta novas competências à SEMARH, com destaque para:elaboração dos planos de desenvolvimento sustentável (inc. I); formulação de políticas de recursos hídricos e meio ambiente (inc. II); e desenvolvimento de estudos, pesquisas e projetos socioeconômicos relacionados ao aproveitamento e preservação dos recursos hídricos (inc. IV).

O Instituto de Gestão das Águas do Rio Grande do Norte (IGARN) é uma autarquia vinculada à SEMARH, instituída através da Lei no 8.086/2002 para exercer a função de órgão de apoio técnico e operacional do SIGERH. É o órgão executivo da política hídrica. Por conseguinte, suas competências são de natureza técnico-operacional, antes atribuídas à SEMARH. Dentre elas destacam-se a análise das solicitações, expedições e fiscalização de outorgas, por delegação da SEMARH. 
O Conselho Estadual de Recursos Hídricos é o órgão colegiado de deliberação coletiva e caráter normativo do SIGERH, que partilha com a SEMARH e os comitês de bacias a responsabilidade pela condução da política hídrica. As competências do Conselho foram fixadas pela lei estadual, no seu art. 21, incisos I a XII. Destacam-se: aprovação, acompanhamento da execução e análise das alterações do PERH; articulação entre os órgãos públicos (estaduais, federais e municipais) e a sociedade civil no encaminhamento da política hídrica estadual; deliberação sobre a criação de $\mathrm{CBHs}$, bem como arbitramento, em grau de recurso, dos conflitos existentes entre bacias ou entre usuários; estabelecimento de critérios para a cobrança pelo uso das águas; e deliberação sobre a criação de agências de bacias hidrográficas. O Decreto Estadual no 13.284/1997, no seu art. 5으, incisos I a XXVIII, fixa outras competências para o Conselho.

A composição do CONERH obedece aos dispositivos do art. 20, incisos I a IV, da Lei no $6.908 / 1996$, combinado com os do art. 60, inc. I a VIII, do Decreto no 13.284/2007. O quadro 2 mostra a composição do Conselho e agrupa seus 32 representantes em 5 grupos.

O decreto estadual inovou ao incluir a categoria dos usuários de recursos hídricos (art. 6ㅇ, $\mathrm{VI}$ ), não prevista na lei estadual. O dispositivo mencionado encontra respaldo na lei das águas que, no seu art. 34, inciso III, apresenta essa categoria na composição do Conselho Nacional de Recursos Hídricos. No âmbito do estado, o decreto detalha no art. $6 \circ$, $\mathrm{VI}, \S 3 \circ$, as sub-categorias de usuários de recursos hídricos, in verbis:

\footnotetext{
"os representantes de que trata o inciso VI serão indicados, respectivamente, pelos irrigantes, pelo órgão ou entidade pública ou outra instituição prestadora de serviço público de abastecimento de água ou de esgotamento sanitário, pelas indústrias, pelas empresas geradoras e autoprodutoras de energia elétrica, pelos pescadores e usuários de recursos hídricos com finalidade de recreação, lazer e turismo."
}

A paridade do CONERH pode ser analisada a partir da origem dos seus 32 representantes. Destes, 16 representam o governo do estado (grupo A) ou entidades federais ou estaduais (grupo B); os outros 16 representam os Comitês de Bacia (grupo C), sociedade civil (grupo D) e usuários. Contudo, o que prejudica a paridade do Conselho é a indicação pelo governo do estado do representante da Companhia de Águas e Esgotos do Rio Grande do Norte (CAERN), empresa de economia mista, vinculada à SEMARH.

Os Comitês de Bacias Hidrográficas são órgãos colegiados de atuação descentralizada em nível de bacias, sub-bacias ou grupo de bacias ou sub-bacias hidrográficas contíguas. Esses colegiados são formados pelos usuários de água, poder público municipal com atuação na bacia hidrográfica, organizações técnicas e de ensino e pesquisa com interesse em recursos hídricos e organizações não governamentais de defesa dos interesses difusos e coletivos da sociedade.

Os primeiros comitês de bacias hidrográficas relatados pela literatura foram implantados em 1988, mas a definição legal da forma como se concebe atualmente advém das leis hídricas estaduais, muitas das quais promulgadas antes da lei das águas.

O marco para a instalação de Comitês de Bacias Hidrográficas no Rio Grande do Norte é a Resolução CONERH № 02, de 15 de dezembro de 2002, o que de certa forma explica a morosidade do processo de instalação dos comitês de bacia potiguares. 


\section{Quadro 2: Composição do Conselho Estadual de Recursos Hídricos, em 2012}

\begin{tabular}{|c|c|}
\hline REPRESENTANTES DO CONSELHO ESTADUAL DE RECURSOS HÍDRICOS & QTDE. \\
\hline $\begin{array}{l}\text { GRUPO (A): Representantes das Secretarias de Estado com interesse no gerenciamento, oferta, controle, } \\
\text { proteção e uso dos recursos hídricos (art. 20, I da Lei no } 6.908 / 1996, \mathrm{C} / \mathrm{c} \text { o art. 6o, I, II e III, do Decreto no } \\
13.284 / 2007 \text { ) }\end{array}$ & 9 \\
\hline $\begin{array}{l}\text { Secretaria do Meio Ambiente e dos Recursos Hídricos (2); Secretaria de Planejamento e Finanças (1); } \\
\text { Secretaria de Agricultura e Abastecimento (1); Secretaria de Indústria, Comércio, Ciência e Tecnologia (1); } \\
\text { Secretaria de Transportes e Obras Públicas (1); Secretaria de Saúde Pública (1); Secretaria de Educação, } \\
\text { Cultura e Desportos (1); Gabinete Civil do Governo do Estado (1). }\end{array}$ & \\
\hline $\begin{array}{l}\text { GRUPO (B): Representantes das entidades governamentais federais e estaduais com atuação no } \\
\text { gerenciamento, oferta, controle, proteção e uso dos recursos hídricos (art. 20, II da Lei no 6.908/1996, c/c } \\
\text { o art. 60, IV e V, do Decreto no 13.284/2007) }\end{array}$ & 7 \\
\hline $\begin{array}{l}\text { Assembléia Legislativa (1); Departamento Nacional de Obras Contra as Secas (1); Fundação Nacional de } \\
\text { Saúde (1); Universidade Federal do Rio Grande do Norte (1); Universidade do Estado do Rio Grande do } \\
\text { Norte (1); Empresa de Pesquisa Agropecuária do Rio Grande do Norte (1); Instituto de Desenvolvimento } \\
\text { Sustentável e Meio Ambiente (1). }\end{array}$ & \\
\hline $\begin{array}{l}\text { GRUPO (C): Representantes indicados pelos Comitês de Bacias Hidrográficas (art. 20, III da Lei no } \\
6.908 / 1996, \text { c/c o art. 6, VIII, § 5, do Decreto no 13.284/2007) }\end{array}$ & 4 \\
\hline Representantes indicados pelos Comitês de Bacias Hidrográficas (4). & \\
\hline $\begin{array}{l}\text { GRUPO (D): Representantes das entidades representativas da sociedade civil (art. 20, IV da Lei no } \\
6.908 / 1996, \text { c/c o art. 6ㅇ, VII, } \S 44^{\circ} \text {, do Decreto } n=13.284 / 2007 \text { ) }\end{array}$ & 6 \\
\hline $\begin{array}{l}\text { Associações de usuários de água (4); organizações técnicas e de ensino e pesquisa (1); organizações não } \\
\text { governamentais (1). }\end{array}$ & \\
\hline GRUPO (E): Representantes de usuários de recursos hídricos (art. 6, VI, § 3ㅇ, do Decreto no 13.284/2007) & 6 \\
\hline $\begin{array}{l}\text { Irrigantes (1); órgão ou entidade pública ou outra instituição prestadora de serviço de abastecimento de } \\
\text { água ou de esgotamento sanitário }{ }^{\left[{ }^{*}\right]}(1) \text {; indústrias (1); empresas geradoras e autoprodutoras de energia } \\
\text { elétrica (1); pescadores (1); recreação, lazer e turismo (1). }\end{array}$ & \\
\hline
\end{tabular}

No estado, o Decreto no 13.284/1997 regulamentou o SIGERH e ampliou as competências dos $\mathrm{CBH}$ dentre as quais se destacam: aprovação do plano de recursos hídricos, do plano diretor, dos programas anuais e plurianuais de aplicação de recursos financeiros em serviços e obras de interesse da gestão dos recursos hídricos, do plano de aplicação dos recursos arrecadados com a cobrança pelo uso da água; e acompanhar a execução do $\mathrm{PERH}$, bem como sugerir providências para o cumprimento de suas metas.

Não obstante a previsão legal, as ações empreendidas pelos CBHs no estado ainda são incipientes. O comitê mais antigo é o do rio Pitimbu, uma sub-bacia da bacia do rio Pirangi, instituído em setembro de 2004 e instalado em janeiro de 2006. Em novembro deste mesmo ano, foi instituído o Comitê da Bacia Hidrográfica do Rio Piancó-Piranhas-Açu, cuja instalação ocorrera somente em outubro de 2009. Recentemente, dois novos comitês estão em fase de instalação: o do rio Ceará-Mirim, instituído em julho de 2010; e o do rio Apodi-Mossoró, em setembro de 2010.

As associações de usuários de água são, por definição do art. $4^{\circ}$, inciso XII, do Decreto $\mathrm{n}^{\circ}$ 13.283/97, "associações civis de direito privado, sem fins lucrativos, com personalidade jurídica, patrimônio e administração próprios, com prazo de duração indeterminado, que congrega e representa os interesses dos usuários de determinada fonte de água." 
Quadro 3: Associações e Comissões de Usuários de Água, por Bacia Hidrográfica, em 2012

\begin{tabular}{|c|c|c|c|c|}
\hline \multicolumn{2}{|r|}{ Bacia Hidrográfica } & \multirow{2}{*}{$\begin{array}{c}\begin{array}{c}\text { Associação } \\
\text { de Usuários }\end{array} \\
8\end{array}$} & \multirow{2}{*}{$\begin{array}{l}\begin{array}{c}\text { Comissão } \\
\text { de Usuários }\end{array} \\
3\end{array}$} & \multirow{2}{*}{$\begin{array}{c}\begin{array}{c}\text { Qtde. de } \\
\text { Municípios }\end{array} \\
11\end{array}$} \\
\hline 1 & Apodi-Mossoró & & & \\
\hline 2 & Piancó-Piranhas-Açu & 22 & 5 & 30 \\
\hline 3 & Boqueirão & 1 & -- & 1 \\
\hline 4 & Punaú & -- & -- & -- \\
\hline 5 & Maxaranguape & -- & -- & -- \\
\hline 6 & Ceará-Mirim & 3 & 1 & 4 \\
\hline 7 & Doce & -- & -- & -- \\
\hline 8 & Potengi & 25 & 6 & 36 \\
\hline 9 & Pirangi & -- & -- & -- \\
\hline 10 & Trairi & 30 & 5 & 35 \\
\hline 11 & Jacu & 4 & -- & 4 \\
\hline 12 & Catu & -- & -- & -- \\
\hline 13 & Curimataú & 2 & 1 & 3 \\
\hline 14 & Guaju & -- & -- & -- \\
\hline 15 & Faixa Litorânea Norte de Escoamento Difuso & 7 & 3 & 10 \\
\hline 16 & Faixa Litorânea Leste de Escoamento Difuso & -- & -- & -- \\
\hline & Totalização & 102 & 24 & 134 \\
\hline
\end{tabular}

Fonte: Elaborado pelos autores, com base no Sistema de Informações (SEMARH, 2012)

Do ponto de vista organizacional, em que pese a morosidade do processo, observa-se o crescimento do número de associações de usuários de água, que já totalizam 102, com perspectiva de ampliação para 126, haja vista a existência de 24 comissões de usuários que se organizam para constituição de suas respectivas associações. Essas organizações estão distribuídas em nove bacias hidrográficas do estado, com cobertura em 134 municípios (quadro 3). É possível que essa ampliação esteja relacionada ao Programa de Incentivo à Criação de Associação de Usuários de Água, criado pela Secretaria de Meio Ambiente e dos Recursos Hídricos. (SEMARH, 2012)

As associações de usuários de águas representam uma alternativa organizacional para a gestão dos recursos hídricos; são espaços privilegiados para discussão dos problemas relacionados à gestão dos recursos hídricos da bacia e podem contribuir com a gestão dos comitês de bacia, bem como indicar representantes para composição do comitê da bacia hidrográfica de sua jurisdição e do Conselho Estadual de Recursos Hídricos.

\section{POLÍTICA ESTADUAL DE RECURSOS HÍDRICOS}

Barbosa (2011) analisa a Política Nacional de Recursos Hídricos com base na Reforma do Estado brasileiro ocorrida nos anos 1990, pautada em mudanças estruturais, nos planos legal, institucional e cultural. Decorre dessa reforma a institucionalização de diversos órgãos no âmbito das administrações direta e indireta, nas esferas da União, Estados-Membros e Distrito Federal. No campo da gestão hídrica, surgiram conselhos de recursos hídricos, comitês de bacias hidrográficas, secretarias de recursos hídricos e meio ambiente, agências de água, planos hídricos, dentre outros órgãos e instrumentos.

Para Granziera (2006, p. 222) "a estrutura do Estado deve estar capacitada para responder às necessidades advindas do cumprimento da norma jurídica, no sentido do exercício de seu poder de polícia". A polícia administrativa, nesse contexto, deve ser compreendida como a atividade da Administração Pública capaz de condicionar a liberdade e a propriedade dos 
indivíduos mediante ação, ora fiscalizadora, ora preventiva, ora repressiva, impondo coercitivamente aos particulares um dever de abstenção a fim de conformar-lhes os comportamentos aos interesses sociais consagrados no sistema normativo.

A partir da reflexão sobre a concepção filosófica de Miguel Reale,a jurista pondera que não apenas a penalidade garante o cumprimento da norma jurídica, haja vista que:

\begin{abstract}
Atualmente, excogitam-se técnicas mais aperfeiçoadas para obter-se o cumprimento das normas jurídicas, através não de sanções intimidativas, mas sim através de processos que possam influir no sentido da adesão espontânea dos obrigados, como os que propiciam incentivos e vantagens. Assim, ao lado das sanções penais, temos as sanções premiais, que oferecem um benefício ao destinatário, como, por exemplo, um desconto ao contribuinte que paga em dia (REALE, 1995, apud GRANZIERA, 2006, p. 222, grifo nosso).
\end{abstract}

E conclui que a lei das águas fornece os contornos necessários à implementação da política hídrica brasileira e seu sistema de gerenciamento. A lei é adequada, mas não é suficiente. É mister que os usuários se organizem e participem ativamente dos comitês de bacias hidrográficas. Deve haver também comprometimento da população, em geral, com a gestão ambiental em sentido amplo e com a gestão hídrica, em particular.

No âmbito do Rio Grande do Norte, a lei estadual no 6.908/1996, no seu art. 2ㅇ (caput), preceitua que a água é um bem de valor econômico e deve ser valorada em todos os seus usos, mas não evidencia o seu caráter de bem de domínio público, nem de recurso natural limitado, como o faz a lei das águas.

A lei estadual adota a bacia hidrográfica como unidade de planejamento e gestão e determina que a distribuição da água no território potiguar obedecerá sempre a critérios sociais, econômicos e ambientais, o que, implicitamente, remete à idéia de uma gestão descentralizada, com a participação do poder público, dos usuários e da comunidade.

As diretrizes gerais dessa lei apontam para os usos múltiplos dos recursos hídricos, proteção das bacias hidrográficas e das águas subterrâneas contra a poluição e a exploração excessiva ou não controlada. Apesar da consonância com as diretrizes da lei das águas, a norma estadual não faz referência à integração das bacias hidrográficas com a dos sistemas estuarinos e zonas costeiras.

\title{
INSTRUMENTOS DE GESTÃO E POLÍTICA HÍDRICA DO RIO GRANDE DO NORTE
}

Granziera (2006, p. 118) classifica os instrumentos da política hídrica nacional em dois tipos ou grupos: os relativos ao planejamento e os dirigidos ao controle administrativo do uso. São instrumentos de planejamento os planos de bacia hidrográfica, a classificação, o enquadramento dos corpos d'água em classes, segundo seus usos preponderantes e os sistemas de informações sobre recursos hídricos. A função precípua desses instrumentos é organizar e definir a utilização da água, solucionando ou minimizando, a priori, os efeitos dos conflitos de interesse sobre esse bem. $O$ instrumento direto de controle do uso é a outorga e, indiretamente, a cobrança pelo uso dos recursos hídricos.

\section{- Plano Estadual de Recursos Hídricos}


Plano de recursos hídricos é o instrumento de planejamento que serve para orientar a execução da política hídrica de um território. O plano nacional estabelece as diretrizes e os programas para o território nacional. Os planos estaduais têm jurisdição circunscrita à realidade de cada Estado-Membro e os planos diretores de bacias hidrográficas limitam-se a cada bacia ou sub-bacia hidrográfica. Os planos nacional, estadual (ou distrital, no caso do Distrito Federal) e de bacia hidrográfica devem apresentar objetivos, metas, meios e recursos a serem empregados para sua realização.

Os planos nacional, estaduais (ou distrital) e de bacias devem manter harmonia ente si; o plano estadual pode, momentaneamente, suprir a ausência dos planos de bacia, enquanto estes não forem elaborados, mas não os substituem porque estes são responsáveis pela abordagem dos recursos hídricos de sua bacia ou sub-bacia, que possuem suas especificidades e demandam estudos próprios e maior nível de aprofundamento.

Os planos devem indicar as melhores alternativas para uso, conservação e proteção dos recursos hídricos. Os estudos devem indicar as forças, oportunidades, fraquezas e ameaças a fim de subsidiar todas as ações a serem empreendidas e servem, principalmente, para: fazer o inventário da água disponível por bacia e as necessidades de água em quantidade suficiente e qualidade adequada para atender à população e suas atividades econômicas; propor instrumentos legais de regulação do uso e conservação das águas; indicar as obras necessárias para garantir, ao longo do tempo, o acesso e o uso racional da água; e formular programas que visem promover as formas mais econômicas e eficientes de utilização das águas.

O primeiro PERH do Rio Grande do Norte foi elaborado pela SEMARH por meio de consultoria especializada (Hidroservice Engenharia Ltda.), que o concluiu em dezembro de 1999. O plano contemplou a análise dos déficits hídricos, a seleção de novos reservatórios para perenização das bacias hidrográficas Piancó-Piranhas-Açu, Apodi-Mossoró e Litoral Leste (quadro 01). Realizou levantamento sobre a pequena e média açudagens e adutoras urbanas e rurais, com ênfase nos seus benefícios e prospecção dos custos para novas construções e manutenção das já existentes.

O estudo aponta os custos com os projetos de irrigação, notadamente com a exploração de águas subterrâneas. Propõe a realização de programas emergenciais de abastecimento da população, considerando quatro níveis de criticidade. Indica a necessidade de um programa de monitoramento em: hidrometeorologia e sedimentometria; hidrogeologia; aspectos fisiográficos; aspectos socioeconômicos e cadastro de áreas irrigadas.

O plano estadual recomenda a realização de estudos específicos acerca do disciplinamento e uso do solo e da política de irrigação do estado. Por fim, propõe a realização de vários programas, classificando-os em ações imediatas (até o ano 2000), ações de curto prazo (2001 a 2005) e ações de médio e longo prazos (2006 a 2017).

Ressalte-se que este primeiro PERH foi concluído em dezembro de 1999, mais de dois após a promulgação da lei hídrica estadual. O prazo revisional de quatro anos previsto na lei (art. 60) e encerrado em dezembro de 2003 também não está sendo observado haja vista que somente em abril de 2011 o processo revisional fora deflagrado pela SEMARH.

O problema da efetividade dos planos e ações governamentais, em certa medida, está relacionado, dentre outros fatores, à falta ou insuficiência de recursos financeiros, falta de prioridade e gestão inadequada ou ineficiente dos recursos públicos. Nesse aspecto particular, cuidou a lei de estabelecer a inserção do PERH no Plano Plurianual de Desenvolvimento do 
Estado, de forma a assegurar a integração setorial em seus aspectos sociais, econômicos e ambientais (art. 7으).

\section{- Enquadramento dos Corpos de Água em Classes}

O enquadramento dos corpos de água é o instrumento através do qual se estabelece a meta de qualidade da água (classe) que deve ser, obrigatoriamente, alcançada ou mantida em um segmento de corpo de água, de acordo com os usos preponderantes pretendidos ao longo do tempo (CONAMA, 2005). Desempenha função essencial na política de gestão dos recursos hídricos, pois se inter-relaciona com os demais, dando-Ihes sentido. Decorre do plano de bacia e se apresenta como a principal referência para a concessão da outorga de direito de uso da água e para a cobrança pelo uso da água, bem como oferece subsídios ao sistema de informações sobre os recursos hídricos.

O enquadramento, assim como os planos de bacias hidrográficas, é referência para os demais instrumentos de gestão dos recursos hídricos (outorga e cobrança) e para os instrumentos de gestão ambiental (licenciamento e monitoramento), sendo, portanto, importante elo entre o Sistema Nacional de Gerenciamento de Recursos Hídricos (SINGERH) e o Sistema Nacional de Meio Ambiente (ANA, 2009).

Barbosa (2011, p. 264), ao destacar que o enquadramento "é imprescindível para se estabelecer um mecanismo de vigilância sobre os níveis de qualidade dos mananciais e para fortalecer a relação entre a gestão dos recursos hídricos e a gestão ambiental", corrobora com esse pensamento e estabelece um elo entre o enquadramento e o Sistema Nacional de Informações sobre Recursos Hídricos (SNIRH). O esquema apresentado na figura 2 é bastante elucidativo para explicar as interfaces existentes entre os instrumentos de gestão da política hídrica brasileira.

O Conselho Nacional do Meio Ambiente, através de sua Resolução 357, disciplina o enquadramento dos corpos de água doce, salobra e salina e as classifica em treze classes de qualidade (de acordo como uso preponderante)e regulamenta dois importantes dispositivos da lei das águas, quais sejam: "assegurar às águas qualidade compatível com os usos mais exigentes a que forem destinadas (art. 9o, I); e "diminuir os custos de combate à poluição das águas" (art. 9o, II).

Figura 2 - Instrumentos da Política de Recursos Hídricos e suas inter-relações

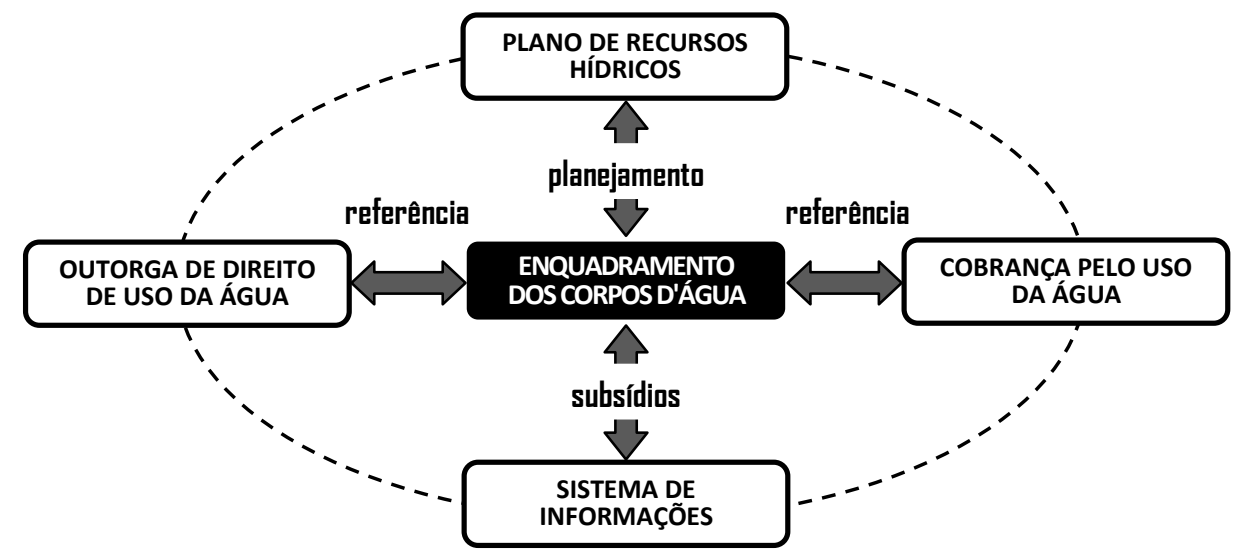


No Rio Grande do Norte, o enquadramento dos corpos d'água não é considerado um instrumento da política estadual de recursos hídricos, embora seja imprescindível para subsidiar a outorga e a cobrança. Essa incongruência pode ser explicada a partir da promulgação da lei estadual, que ocorrera antes da lei das águas, norma que instituiu referido instrumento.

O governo estadual, através do Decreto no 9.100/1984, enquadrou cursos e reservatórios d'água do estado com base na classificação estabelecida na Portaria no 13/1976, do antigo Ministério do Interior. Essa Portaria deu origem a Resolução CONAMA n 20/1986, que "dispõe sobre a classificação das águas doces, salobras e salinas do território nacional" e, por conseguinte, a revoga tacitamente. Mais tarde, essa mesma Resolução é revogada expressamente pela Resolução CONAMA no 357/2005, que "dispõe sobre a classificação dos corpos de água e diretrizes ambientais para o seu enquadramento [...]". Desse modo, conclui-se que o Decreto estadual também se encontra revogado e, portanto, o estado não dispõe de regulamentação própria para o enquadramento dos recursos hídricos.

\section{- Sistema de Informações sobre Recursos Hídricos}

O modelo de gestão integrada e participativa dos recursos hídricos (modelo sistêmico) pressupõe a participação da sociedade no processo decisório. Sendo assim, o SNIRH é instrumento essencial porque a disponibilização de informações confiáveis é determinante para auxiliar na tomada de decisões seguras e responsáveis por parte do poder público, dos usuários e das comunidades, bem como "harmoniza-se com o princípio constitucional do direito à informação", conforme assevera Barbosa (2011, p. 272).

A lei das águas definiu o SNIRH, no seu art. 25, como "sistema de coleta, tratamento, armazenamento e recuperação de informações sobre recursos hídricos e fatores intervenientes em sua gestão". A responsabilidade pela organização, implantação e gestão desse sistema cabe, por determinação contida no art. 4으, inciso XIV, da Lei no 9.984/2000, à Agência Nacional de Águas (ANA).

Os objetivos do SNIRH estão delineados no art. 27 da lei das águas. São eles: reunir, dar consistência e divulgar dados e informações sobre a situação qualitativa e quantitativa dos recursos hídricos no Brasil (inc. I); atualizar permanentemente as informações sobre a disponibilidade e demanda de recursos hídricos em todo o território nacional (inc. II); e fornecer subsídios para a elaboração dos planos de recursos hídricos (inc. III).

A Resolução CNRH no 13/2000 no seu art. 1ำ, com fulcro na Lei no 9.984/2000, atribui à ANA a função de coordenação dos órgãos e entidades federais com atribuições ou competências relacionadas à gestão dos recursos hídricos com vistas à gestão integrada das águas e em especial a produção, consolidação, organização e disponibilização à sociedade das informações e ações referentes:

\footnotetext{
a) à rede hidrométrica nacional e às atividades de hidrologia relacionadas com o aproveitamento de recursos hídricos;

b) aos sistemas de avaliação e outorga dos recursos hídricos superficiais e subterrâneos, em todo território nacional;

c) aos sistemas de avaliação e concessão das águas minerais;
} 

d) aos sistemas de coleta de dados da Rede Nacional de Meteorologia;
e) aos sistemas de informações dos setores usuários;
f) ao sistema nacional de informações sobre meio ambiente;
g) ao sistema de informações sobre gerenciamento costeiro;
h) aos sistemas de informações sobre saúde;
i) a projetos e pesquisas relacionados com recursos hídricos; e
j) a outros sistemas de informações relacionados à gestão de recursos hídricos.

Para atender a todas as exigências legais, a ANA desenvolveu o SNIRH através de uma plataforma de suporte computacional composta de subsistemas, base de dados, plataforma de integração, infraestrutura computacional e, recursos humanos e organizacionais que sustentam o desenvolvimento e a operação do sistema (ANA, 2012). As informações disponíveis no SNIRH podem ser acessadas livremente através do sítio da Agência na Internet.

No Rio Grande do Norte o Sistema de Informações sobre Recursos Hídricos, da mesma forma como ocorre com o enquadramento, não é considerado um instrumento da política estadual de recursos hídricos, não obstante sua relevância para a efetiva implementação da gestão integrada e participativa das águas, fato reconhecido pelo legislador da lei hídrica estadual que incluiu no rol das competências da SEMARH a necessidade de "implantar e manter banco de dados sobre os recursos hídricos do estado." (art. 25, inc. V)

A SEMARH ainda não dispõe de um sistema de informações sobre os recursos hídricos do território potiguar. Contudo, informações de caráter geral relacionadas ao plano estadual de recursos hídricos (síntese), à situação volumétrica dos reservatórios das bacias, e às associações e comissões de usuários de água podem ser obtida através de seu portal na Internet.

\section{- Outorga e Licenciamento de Obras Hídricas}

A outorga de direito de uso de recursos hídricos nos termos da lei das águas é o ato administrativo mediante o qual o poder público outorgante faculta ao outorgado (pessoa física ou jurídica) o direito de uso de recurso hídrico por prazo determinado.

É ato administrativo cuja titularidade é do poder executivo, que objetiva assegurar o controle quantitativo e qualitativo dos usos múltiplos da água, bem como o efetivo exercício dos direitos de acesso à água. $O$ poder executivo exerce esse mandamento legal através da ANA, conforme disposto no art. 4으, inciso IV, da Lei no 9.984/2000, que a instituiu. A ANA, por sua vez,"poderá delegar ou atribuir a agências de água ou de bacia hidrográfica a execução de atividades de sua competência" dentre as quais a outorga de uso de recursos hídricos, exceto no caso dos potenciais hidrelétricos.

A não obrigatoriedade de requerer outorga de direito de uso de recursos hídricos limitase às seguintes situações: usos de água para satisfação das necessidades de pequenos núcleos populacionais de comunidades rurais; derivações, captações e lançamentos considerados insignificantes; e acumulações de volumes considerados insignificantes. Nas demais situações, a requisição da outorga é obrigatória e sua inobservância consiste em infração, nos termos do art. 49, inciso I, da Lei no 9.433/97.

A Resolução CNRH № 16/2001 estabelece os critérios gerais para emissão de outorgas e vincula sua concessão e manutenção à observância dos planos de recursos hídricos e, em especial: às prioridades de uso estabelecidas; à classe em que o corpo de água estiver enquadrado, em consonância com a legislação ambiental; à preservação dos usos múltiplos 
previstos e; à manutenção das condições adequadas de transporte aquaviário, quando couber (art. 12 e incisos).

A articulação dos procedimentos para obtenção da outorga de direito de uso de recursos hídricos com os procedimentos de licenciamento ambiental são disciplinados pela Resolução CNRH no 65/2006. A concessão da licença de operação para empreendimentos fica condicionada à apresentação da outorga ao órgão ambiental licenciador.

$\mathrm{Na}$ política hídrica estadual a outorga de direito de uso dos recursos hídricos e o licenciamento de obras de oferta hídrica são um instrumento único de gestão. Este instrumento, previsto no art. 4으, inciso III, da lei hídrica estadual é regulamentado pelo Decreto no 13.283/1997, que define obras ou serviços de oferta hídrica como "a implantação, ampliação ou alteração de projeto de qualquer empreendimento que demande a utilização de recursos hídricos, superficiais ou subterrâneos, bem como a execução de obras ou serviços que alterem o seu regime em quantidade e/ou qualidade." (art. 4으, XI)

A Resolução Conjunta CONERH/CONEMA no 01 estabelece as diretrizes para a concessão da outorga de direito de uso dos recursos hídricos e da licença ambiental, respeitadas as competências dos órgãos integrantes do SIGERH e do Sistema Estadual de Meio Ambiente (SISEMA). Esta Resolução regulamenta o art. 56 do Decreto no 13.283/1997, segundo o qual a SEMARH e o Instituto de Desenvolvimento Sustentável e Meio Ambiente do Rio Grande do Norte (IDEMA), órgão licenciador do estado, "articular-se-ão visando a integrar suas respectivas licenças, de maneira a evitar-se repetição de exigências, aproveitando-se, sempre que possível, os elementos fornecidos para uma e outra licença". A pretensão expressa na Resolução objetiva o compartilhamento de informações e a compatibilização dos procedimentos na análise e decisão em suas esferas de competência.

A ordem de prioridade para concessão de outorga estabelecida no art. 9o, caput e incisos do decreto estadual encontra-se em consonância com as leis hídricas estadual e federal e prioriza, nessa ordem: consumo humano em residências, hospitais, estabelecimentos de ensino, quartéis, presídios e outros estabelecimentos coletivos; consumo humano em entidades públicas ou privadas; dessedentação animal; produção rural (irrigação, pecuária, piscicultura); produção industrial, comercial e prestação de serviços; e outros fins definidos pelo CONERH.

O órgão competente em matéria de outorga e licenciamento de obras hídricas é a SEMARH, que, na forma da Lei no 8.086/2002, art. 3으, incisos VI e VIII, respectivamente, pode delegar essas competências ao IGARN.

A concessão de outorga, independentemente da transcrição no instrumento concessivo, estará sujeita à disponibilidade hídrica, à observância dos usos prioritários, à comprovação de não poluição e desperdícios significativos, e à apresentação de licença prévia, quando se tratar de uso que dependa de obras ou serviços de oferta hídrica. Com isso, quis o legislador do decreto estadual evidenciar que a outorga pode ser revogada em qualquer tempo, sempre que uma ou mais das condições acima descritas deixarem de ser observadas.

O mesmo decreto estabelece, no seu art. 13, que "a disponibilidade hídrica será avaliada em função das características hidrológicas ou hidrogeológicas da bacia superficial ou subterrânea". No art. 17, ao tratar dos critérios de quantificação, estabelece que "a soma dos volumes d'água outorgados numa determinada bacia não poderá exceder $9 / 10$ (nove décimos) da vazão regularizada anual com $90 \%$ (noventa por cento) de garantia". 
Ottoni et al (2011) analisaram o ambiente interno da SEMARH e do IGARN a partir de entrevistas realizadas com técnicos desses órgãos e elaboraram a correspondente Matriz de SWOT (Strengths, Weaknesses, Opportunities e Threats), metodologia que possibilita analisar os fatores que influenciam o funcionamento das organizações com base nos seus pontos fortes (forças), pontos fracos (fraquezas), oportunidades e ameaças. O estudo, apresentado no quadro 4, foi desenvolvido no período de junho a setembro de 2009 e tomou por base somente os pontos fortes e os pontos fracos, considerando que se limitou ao ambiente interno das organizações.

\section{Quadro 4: Resultado da análise de SWOT para o processo de emissão de outorga de direito de uso de água pela SEMARH}

\begin{tabular}{|l|l|}
\hline \multicolumn{1}{|c|}{ FORÇAS } & \multicolumn{1}{c|}{ FRAQUEZAS } \\
\hline - Legislação para o tema; & $\begin{array}{l}\text { - Plano de recursos hídricos desatualizado e não } \\
\text { especializado para subsidiar as análises da } \\
\text { - Plano e estudos sobre recursos hídricos no } \\
\text { Estado; }\end{array}$ \\
- Integração entre os procedimentos de & $\begin{array}{l}\text { - Ausência de um eficiente sistema de informações } \\
\text { Sobre recursos hídricos; }\end{array}$ \\
- Flicenciamento ambiental e outorga; & - Ausência do monitoramento permanente da \\
- Recursos financeiros para implantação de & quantidade e qualidade das águas do Estado; \\
projetos; & - Ausência de dados que subsidiem a emissão dos \\
- Corpo técnico experiente; & pareceres; \\
- Multidisciplinaridade entre os técnicos; & - Fiscalização incipiente; \\
- Incentivo à capacitação dos profissionais; & - Equipe técnica insuficiente; \\
- Tempo de emissão de acordo com o permitido na & - Falta de equipe técnica permanente; \\
legislação. & - Equipe técnica dispersa em vários setores e \\
& prédios; \\
& - Equipe técnica com acúmulo de funções; \\
& - Equipamentos de informática obsoletos; \\
& - Burocracia de alguns setores; \\
& - Ausência de automóveis exclusivos para o setor. \\
\hline
\end{tabular}

Fonte: OTTONI et al (2011, p. 68).

A análise das informações apresentadas no quadro 4 pode ser feita a partir de quatro categorias, a saber: base legal(considerada adequada à condução da política hídrica estadual), instrumentos de gestão da política hídrica, processos e infraestrutura.

Dentre os instrumentos de gestão apresentados, destaca-se a importância da vinculação entre outorga e licenciamento ambiental. A desatualização do PERH e a falta de um sistema de informações eficiente são consideradas como fragilidades da política hídrica. A pesquisa de Ottoni et al não menciona a cobrança pelo uso dos recursos hídricos.

A avaliação dos processos é considerada satisfatória devido à adequação dos seus fluxos, o que possibilita o cumprimento dos prazos, não obstante o excesso de burocracia presente em alguns setores.

A infraestrutura de pessoal e de equipamentos requer atenção especial. O pessoal técnico destaca-se pela experiência e capacidade de trabalho em equipe (multidisciplinaridade). Porém, o número insuficiente de servidores e a dispersão destes em vários setores gera o acúmulo de funções e dificulta a realização do trabalho. Do ponto de vista material, as principais dificuldades estão relacionadas à obsolescência dos equipamentos de informática e à falta de transporte para as atividades de campo.

Por fim, a ausência (ou insuficiência) de dados para subsidiar a elaboração dos pareceres, decorrente da desatualização do PERH e da inexistência de um sistema de informações; e, a falta 
de monitoramento (permanente) da quantidade e qualidade das águas e a fiscalização incipiente, decorrentes dos problemas de infraestrutura, comprometem a eficiência e a eficácia da política hídrica estadual.

\section{- Cobrança pelo Uso da Água}

A cobrança pelo uso de recursos hídricos é o instrumento de gestão instituído pela Lei no 9.433/1997 que tem como objetivos estimular o uso racional da água e gerar recursos financeiros para investimentos na recuperação e preservação dos mananciais das bacias hidrográficas.

A cobrança é instrumento econômico e de gestão hídrica. É instrumento de gestão na medida em que contribui para "reconhecer a água como bem econômico e dar ao usuário uma indicação de seu valor econômico" (art. 19, I) e, principalmente, para "incentivar a racionalização do uso da água" (art. 19, II). É também instrumento econômico porque visa "obter recursos financeiros para o financiamento dos programas e intervenções contemplados nos planos de recursos hídricos" (art. 19, III).

Segundo Barbosa (2011, p. 268-269) a cobrança visa eliminar as externalidades que podem advir do uso irracional das águas. O sentido da cobrança apresenta ligações com o princípio do poluidor-pagador que, posteriormente, foi alargado para o princípio do usuáriopagador, situação em que o usuário é obrigado a internalizar os custos que impõe a terceiros ao usar o recurso natural. É o princípio utilizado para a cobrança pela água bruta (água disponível no ambiente, in natura) que serve de elemento indutor do uso moderado dos recursos hídricos.

A implementação da cobrança se dá mediante pactuação entre os poderes públicos, os setores usuários e as organizações civis representadas no âmbito de cada Comitê de Bacia, com o apoio do órgão gestor de recursos hídricos, de acordo com a dominialidade das águas. Os mecanismos e valores são propostos pelo Comitê de Bacia e aprovados pelo CNRH ou pelo Conselho Estadual de Recursos Hídricos, seguindo também o critério da dominialidade.

A cobrança pelo uso de recursos hídricos está condicionada à implementação dos demais instrumentos da política hídrica, conforme disposto no art. 7으, caput e inciso IX e no art. 20, caput, da lei das águas. A Resolução CNRH no 48/2005 estabeleceu critérios gerais para a cobrança pelo uso dos recursos hídricos a serem observados pelos entes União, estados e Distrito Federal e realçou no seu art. 3ำ que "a cobrança deverá estar compatibilizada e integrada com os demais instrumentos de política de recursos hídricos".

Os critérios para a cobrança estão delineados no art. 60 e incisos da referida resolução. São eles: cadastramento dos usuários da bacia; processo de regularização de usos de recursos hídricos sujeitos à outorga; e implementação das agências de bacia ou entidade delegatária de suas funções.

O Rio Grande do Norte, não obstante previsão legal no art. 4ํ, inciso IV, da lei hídrica estadual, ainda não implementou a cobrança pelo uso da água no seu território. A implementação desse instrumento depende da superação de alguns desafios dentre os quais se destacam a criação e o efetivo funcionamento dos comitês de bacia, o cadastramento dos usuários, a regularização dos usos múltiplos das águas e a implementação das agências de bacias ou congêneres.

\section{- Fundo Estadual dos Recursos Hídricos}


A experiência brasileira sobre os mecanismos de financiamento dos grandes projetos hidráulicos e das políticas de recursos hídricos indica que cada um desses sub-setores desenvolveu seus próprios sistemas de financiamento. Tucci (2001, p. 96) destaca que muitos programas foram financiados inicialmente com verbas públicas e, posteriormente, adotaram outras estratégias a exemplo do que ocorrera com os setores de produção de energia elétrica e saneamento que passaram a ser financiados, em parte, pela cobrança de tarifas.

A estratégia da cobrança pelo uso dos recursos hídricos se constitui numa alternativa de geração de receitas, mas não se aplicaria como alternativa geral para o país, sendo mais apropriada para as bacias com elevada densidade de atividades e de usuários de água, como apontado no Plano Nacional de Recursos Hídricos - prioridades 2012-2015 (MMA, 2011).

Os valores arrecadados com a cobrança pelo uso dos recursos hídricos nas bacias hidrográficas dos rios Piracicaba, Capivari, Jundiaí (bacia PCJ), Paraíba do Sul e São Francisco, em 2010, correspondem, respectivamente, a $12,2 \%, 6,5 \%$ e 0,35\% da demanda anual de recursos financeiros para essas bacias, conforme dados apresentados no documento acima referenciado (MMA, 2011). A realidade dessas bacias federais que implementaram o instrumento da cobrança indica a necessidade de outras estratégias de financiamento para uma adequada gestão dos recursos hídricos.

A criação dos chamados fundos setoriais foi a fórmula encontrada pelo poder público para assegurar recursos financeiros necessários ao subsídio das diversas atividades dos setores hídricos, com a vantagem de serem isentos de contingenciamentos de suas receitas por parte do poder executivo. No Brasil ainda não existe um fundo nacional de recursos hídricos, mas emergem os fundos estaduais como possibilidade de viabilização econômica e descentralização da gestão hídrica.

Os fundos estaduais de recursos hídricos são instrumentos econômicos instituídos a partir da lei das águas e das leis hídricas estaduais. Segundo Guimarães, Lemos e Xavier (2008, p. 2442), são "fundos financeiros atrelados a uma política pública específica para a gestão da água" e sua função é "possibilitar o retorno de recursos financeiros arrecadados e geridos pela esfera governamental para as bacias hidrográficas nas quais foram gerados".

O documento Conjuntura dos Recursos Hídricos no Brasil (ANA, 2012) destaca que as informações sobre os fundos estaduais de recursos hídricos são ainda bastante precárias e referem-se apenas aos recursos previstos na legislação e não nas efetivas alocações. Aponta ainda que dos 24 fundos estaduais, 9 ainda não foram regulamentados e apenas 8 encontram-se em funcionamento.

O Fundo Estadual de Recursos Hídricos do Rio Grande do Norte foi criado pela Lei no 6.908/1996 e regulamentado pelo Decreto no 13.836/1998, conforme estabelece o art. 12 da lei estadual. As finalidades do fundo estadual são oferecer suporte financeiro às ações e programas da política hídrica do estado, promover o desenvolvimento dos recursos hídricos com vistas à melhoria da qualidade de vida da população, em equilíbrio com o meio ambiente, e assegurar os meios necessários à execução das atividades dos órgãos do SIGERH.

As fontes de recursos do FUNERH previstas no art. 13, incisos I a IX, da lei estadual foram ampliadas de 9 para 12, conforme estabelece o Decreto no 13.836/1998, no art. 2o, incisos I a XII. Dentre elas, destacam-se: recursos do Tesouro do Estado e municípios; compensações financeiras que o estado receber pelo aproveitamento hidroenergético, recursos minerais (petróleo e gás natural); rendas provenientes de aplicações financeiras (do próprio 
fundo); doações de pessoas físicas ou jurídicas; transferências da União destinadas à execução de planos e programas de recursos hídricos; cobrança pela utilização de recursos hídricos; multas aplicadas aos infratores da legislação hídrica; contribuições, tarifas e taxas cobradas de beneficiários de obras e serviços de aproveitamento e controle dos recursos hídricos.

O Decreto no 13.285/1997 desvinculou o FUNERH da antiga SERHID, como previa anteriormente o art. 80 da política hídrica estadual, e o vinculou diretamente ao secretário de recursos hídricos (art. 4요 § 1으, alínea "a"). Posteriormente, o Decreto no 13.836/1998 manteve a mesma vinculação, mas definiu no seu art. 5 (caput) que doravante a supervisão do fundo cabe ao CONERH.

Na realidade, a participação do CONERH na gestão desse fundo, inserta no art. 5o, caput, combinada com o art. 8으, inciso $\mathrm{V}$, limita-se à aprovação do relatório anual das atividades do FUNERH e, portanto, passa ao largo, por exemplo, do modelo dos comitês gestores dos fundos setoriais de ciência, tecnologia e inovação que tem as prerrogativas legais de definir as diretrizes, ações e planos de investimentos, com ampla participação da sociedade nas decisões sobre aplicação dos recursos, gestão compartilhada, planejamento, concepção, definição e acompanhamento das ações.

Por fim, três questões importantes emergem dessa análise. A primeira diz respeito à vinculação direta do Fundo ao Secretário da SEMARH, fato que prejudica a gestão descentralizada (figura 01). A segunda relaciona-se às transferências da União que exigem um PERH atual e que reflita as reais necessidades do estado e da sociedade. A última refere-se às condições operacionais do IGARN para analisar, emitir, fiscalizar e também aplicar as sanções quando se fizer necessário.

\section{CONSIDERAÇÕES FINAIS}

A principal inovação da política hídrica nacional consiste na concepção de um modelo sistêmico de gestão, baseado nos princípios da descentralização, no planejamento compartilhado e na gestão participativa dos atores sociais. A eficiência do novo sistema depende da implementação dos comitês de bacia, das agências de bacia e da implementação dos instrumentos de gestão.

A antecipação da promulgação da lei hídrica estadual em relação à federal contribuiu para o avanço da gestão das águas no território potiguar na medida que estabeleceu os objetivos, as diretrizes e os instrumentos da política hídrica, bem como determinou a criação do Sistema Integrado de Gerenciamento dos Recursos Hídricos e seus respectivos órgãos (Secretaria de Estado do Meio Ambiente e dos Recursos Hídricos, Conselho Estadual de Recursos Hídricos e Comitês de Bacias Hidrográficas). Não obstante, a existência de apenas dois comitês de bacia em funcionamento e dois em implantação no âmbito das 16 bacias hidrográficas, denota o caráter incipiente da gestão hídrica sistêmica do estado.

As principais limitações para uma gestão participativa e descentralizada das águas no Rio Grande do Norte estão relacionadas aos instrumentos de gestão, às condições de funcionamento dos órgãos do SIGERH, à centralização nos procedimentos de concessão de outorga e de licenciamento e ao caráter centralizador presente na administração do fundo estadual de recursos hídricos. 
O primeiro plano de gestão, criado para o período 1999-2003, ainda vige sem a necessária atualização, prevista em lei. A falta de informações técnicas atualizadas e, portanto, confiáveis, sobre os corpos hídricos, é fator limitante à concessão de outorgas de direito de uso dos recursos hídricos. Quanto aos demais instrumentos da política hídrica estadual, destacam-se a falta de previsão legal do enquadramento dos corpos d'água, a inexistência de um sistema de informações sobre recursos hídricos e a falta de regulamentação para implementação da cobrança pelo uso dos recursos hídricos.

Quanto às condições de funcionamento dos órgãos do SIGERH, o estudo mostra que na SEMARH o número de servidores é insuficiente e a dispersão destes em vários setores gera o acúmulo de funções e dificulta a realização do trabalho. Do ponto de vista material, as principais dificuldades estão relacionadas à obsolescência dos equipamentos de informática e à falta de transporte para as atividades de campo.

As concessões de outorga e de licenciamento em águas estaduais são de responsabilidade da SEMARH que, diretamente ou por delegação ao IGARN, analisa os pedidos, decide sobre a concessão, recolhe taxas, fiscaliza e pode aplicar penalidades, se for o caso. Essas práticas administrativas revelam um caráter centralizador que pode conduzir à ineficiência dos serviços prestados pelo Estado.

Embora a delegação conferida por lei assegure ao IGARN as prerrogativas de analisar, expedir e fiscalizar outorgas referentes aos recursos hídricos de dominialidade estadual, essa multiplicidade de funções pode prejudicar a lisura do processo, vez que, no que pese a probidade do agente público, a melhor doutrina recomenda que essas funções sejam desempenhadas por agentes públicos distintos o que garantiria mais transparência ao procedimento.

A administração do fundo estadual de recursos hídricos também revela o caráter centralizador na medida em que este se encontra vinculado diretamente ao Secretário da SEMARH, embora o decreto estadual regulamentador estabeleça critérios para sua utilização. Informações sobre o montante de recursos financeiros do FUNERH, bem como sua execução não estão disponíveis para consulta, o que prejudica o critério da transparência.

Os principais avanços para uma gestão hídrica participativa e descentralizada no estado são a produção normativa especializada (leis, decretos, regulamentos), a criação do SIGERH, da SEMARH (órgão gestor da política hídrica), do CONERH (órgão deliberativo e normativo), do IGARN (órgão executivo, de natureza técnico-operacional) e dos Comitês de Bacias Hidrográficas. Destaca-se, ainda, a iniciativa do estado em fomentar a criação de associações de usuários de recursos hídricos, uma forma alternativa de organização para a gestão participativa e descentralizada das águas.

Em que pesem as limitações discutidas no presente trabalho, a implementação dos instrumentos de gestão hídrica no estado apresentam resultados importantes, dentre os quais destacam-se: vinculação entre a concessão de outorga e o licenciamento de obras hídricas; criação e regulamentação do fundo estadual de recursos hídricos; análise dos déficits hídricos; seleção de novos reservatórios para perenização de bacias hidrográficas; levantamento sobre a pequena e média açudagens e adutoras urbanas e rurais; levantamento de custos com projetos de irrigação, notadamente com a exploração de águas subterrâneas; proposição de programas emergenciais de abastecimento; proposição de programa de monitoramento em hidrometeorologia e sedimentometria, hidrogeologia, aspectos fisiográficos, aspectos socioeconômicos e cadastro de áreas irrigadas; recomendação sobre a necessidade de estudos específicos sobre irrigação e disciplinamento e uso do solo. 
Assim, apesar de a gestão dos recursos hídricos no Rio Grande do Norte ainda apresentar fortes traços do modelo econômico-financeiro que se caracteriza pelo planejamento estratégico, instrumentos econômicos e pela tecnocracia, a produção normativa e as iniciativas do estado, ainda que marcadas pela morosidade, indicam a possibilidade de mudança para o modelo sistêmico.

A melhoria da gestão hídrica estadual depende, principalmente, do aperfeiçoamento dos instrumentos de gestão e das condições de infraestrutura e de pessoal dos órgãos do SIGERH. Adequando-se a infraestrutura (transporte, equipamentos) e o quadro de pessoal desses órgãos, será possível desenvolver ações importantes, tais como: fortalecimento do programa de incentivo à criação de associações de usuários de água como forma alternativa de organização para uma gestão participativa e descentralizada; mobilização dos atores sociais das bacias hidrográficas; celeridade nos processos de constituição dos comitês de bacia; e criação das agências de bacia.

Quanto aos instrumentos de gestão, destaca-se: a necessidade de atualização do plano de recursos hídricos; a instituição do enquadramento dos corpos de água e do sistema de informações sobre recursos hídricos como instrumentos da política hídrica estadual; a regulamentação da cobrança pelo uso dos recursos hídricos; e a vinculação do fundo de recursos hídricos ao CONERH como forma de ampliar a participação da sociedade nas decisões sobre aplicação dos recursos, gestão compartilhada, planejamento, concepção, definição e acompanhamento das ações.

\section{REFERÊNCIAS BIBLIOGRÁFICAS}

1. AgÊNCIA EXECUTIVA DE GESTÃO DAS ÁGUAS DO ESTADO DA PARAÍBA (AESA).Comitê Piranhas-Açu. Disponível em: <http://www.aesa.pb.gov.br/comites/piranhasacu/>. Acesso em: 10 nov. 2012.

2. AGÊNCIA NACIONAL DE ÁGUAS (ANA). Conjuntura dos recursos hídricos no Brasil: informe 2012. Ed. especial. Brasília: ANA, 2012. 215p.:il.

3. Implementação do enquadramento em bacias hidrográficas no Brasil; Sistema nacional de informações sobre recursos hídricos - Snirh no Brasil: arquitetura computacional e sistêmica. Brasília: ANA, 2009. 145p.: il. (Cadernos de recursos hídricos; 6).

4. Portal da qualidade das águas - Curso enquadramento portal 2010. Disponível em: <http://pnqa.ana.gov.br/Publicao/CursoEnquadramentoPortal2010.pdf>. Acesso em: 20 nov. 2012.

5. BARBOSA, E. M. Direito ambiental e dos recursos naturais: biodiversidade, petróleo e água. Belo Horizonte: Fórum, 2011. 297p.

6. BRASIL. Decreto no 4.613, de 11 de março de 2003. Regulamenta o Conselho Nacional de Recursos Hídricos, e dá outras providências. Disponível em: <https://www.planalto.gov.br/ ccivil_03/decreto/d24643.htm>. Acesso em: 10nov. 2012. 
7. Decreto no 24.643, de 10 de julho de 1934. Decreta o Código de Águas. Disponível em: <https://www.planalto.gov.br/ccivil_03/decreto/d24643.htm>. Acesso em: 10 nov. 2012.

8. Lei no 9.984, de 17 de julho de 2000. Dispõe sobre a criação da Agência Nacional de Águas e dá outras providências. Disponível em: <https://www.planalto.gov.br/ ccivil_03/ leis/19984.htm>. Acesso em: 10nov. 2012.

9. Lei no 9.433, de 8 de janeiro de 1997. Institui a Política Nacional de Recursos Hídricos e cria o Sistema Nacional de Gerenciamento de Recursos Hídricos, Disponível em: <https://www. planalto.gov.br/ccivil_03/leis/I9433.htm>. Acesso em: 10nov. 2012.

10. CONSELHO NACIONAL DE RECURSOS HÍDRICOS (CNRH). Resolução no 48, de 21 de março de 2005. Estabelece critérios gerais para a cobrança pelo uso de recursos hídricos. Disponível em: <http://www.cnrh.gov.br/sitio/index.php?option=com_content\&view= article\&id=14>. Acesso em: 22 nov. 2012.

11. CONSELHO NACIONAL DO MEIO AMBIENTE (CONAMA). Resolução no 357, de 17 de março de 2005. Dispõe sobre a classificação dos corpos de água e diretrizes ambientais para o seu enquadramento, bem como estabelece as condições e padrões de lançamento de efluentes e dá outras providências. Disponível em: <http://www.mma.gov.br/port/ conama/legiabre.cfm?codlegi=459>. Acesso em: 15nov. 2012.

12. FERREIRA, M. I. P.; SILVA, J. A. F. da; WERNECK, B. R. Marcos conceituais para a gestão de recursos hídricos. In: Capacitação e mobilização do norte-noroeste fluminense para criação de organismos de bacia na Região Hidrográfica IX do Estado do Rio de Janeiro. Revista Boletim do Observatório Ambiental Alberto Ribeiro Lamego [online]. 2008, v.2, n.2, p.37-57. ISSN 1981-6197. Disponível em: <http://www.essentiaeditora.iff.edu.br/index. php/boletim/article/view/244/227>. Acesso em: 15 nov. 2011.

13. GRANZIERA, M. L. M. Direito de águas: disciplina jurídica das águas doces. 3. ed. São Paulo: Atlas, 2006. 252p.

14. GUIMARÃES, P. B. V.; LEMOS, R. D. D.; XAVIER, Y. M. de A. Fundos estaduais de recursos hídricos: a sustentabilidade econômica do sistema descentralizado de gestão. In: CONGRESSO NACIONAL DO CONSELHO NACIONAL DE PESQUISA E PÓS-GRADUAÇÃO EM DIREITO (CONPEDI), Brasília. Anais. Brasília: 2008. Disponível em: <http://www. conpedi.org.br/manaus/arquivos/anais/brasilia/13_225.pdf>. Acesso em: 26 nov. 2012.

15. MINISTÉRIO DO MEIO AMBIENTE (MMA). CBH Piranhas-Açu.Disponível em: <http:// www.piranhasacu.cbh.gov.br/instalacao.aspx>. Acesso em: 12 nov. 2012.

16. _. Plano nacional de recursos hídricos: prioridades 2012-2015. Publicações [online]. 2011. 124p. Disponível em: <http://www.mma.gov.br/publicacoes/agua/category/42recursos-hidricos?start=20>. Acesso em: 26 nov. 2012.

17. OTTONI, B. M. de P. et al. A outorga do direito de uso dos recursos hídricos no Rio Grande do Norte. Revista Holos [online]. 2011, ano 27, v. 1, p. 57-71. ISSN 1807-1600. Disponível em: <http://www.essentiaeditora.iff.edu.br/index.php/boletim/article/view/ 244/227>. Acesso em: 10 nov. 2012.

18. POMPEU, C. T. Direito das Águas no Brasil. 2. ed. São Paulo : Editora Revista dos Tribunais, 2010. 475p. 
19. PORTO, M. F. A.; PORTO, R. La L. Gestão de bacias hidrográficas. Estudos Avançados [online]. 2008, vol. 22, n. 63, p. 43-60.

20. RIO GRANDE DO NORTE. Decreto no 17.789, de 14 de setembro de 2004. Institui o Comitê da Sub-bacia Hidrográfica do Rio Pitimbu e dá outras providências. Disponível em: <http://www.semarh.rn.gov.br/>. Acesso em: 16nov. 2012.

21. __. Decreto no 13.836, de 11 de março de 1998. Regulamenta o Fundo Estadual de Recursos Hídricos - FUNERH e da outras providências. Disponível em: <http://www. semarh.rn.gov.br/>. Acesso em: 16nov. 2012.

22. _. Decreto no 13.285, de 22 de março de 1997. Aprova o Regulamento da Secretaria de Recursos Hídricos. Disponível em: <http://www.semarh.rn.gov.br/>. Acesso em: 16 abr. 2012.

23.

Decreto no 13.284, de 22 de março de 1997. Regulamenta o Sistema Integrado de Gestão de Recursos Hídricos - SIGERH, e dá outras providências. Disponível em: <http:// www.semarh.rn.gov.br/>. Acesso em: 17nov. 2012.

24.

Decreto no 13.283, de 22 de março de 1997. Regulamenta os incisos III do art. 4으 da Lei $\mathrm{n}$ - 6.908, de 01 de julho de 1996, que dispõe sobre a Política Estadual de Recursos Hídricos, e dá outras providências. Disponível em: <http://www.semarh.rn.gov.br/>. Acesso em: 18nov. 2012.

25.

Decreto $\mathrm{n}$ 9 9.100, de 22 de outubro de 1984. Enquadra cursos e reservatórios d'água do Estado na classificação estabelecida na Portaria no 13, de 15 de janeiro de 1976, do Ministro do Interior, e dá outras providências. Disponível em: <http://www. semarh.rn.gov.br/>. Acesso em: 19nov. 2012.

26. L_ Lei Complementar no 163, de 5 de fevereiro de 1999. Dispõe sobre a organização do Poder Executivo do Estado Rio Grande do Norte e dá outras providências. Disponível em: <http://www.gabinetecivil.rn.gov.br/acess/pdf/leicom163-.pdf>. Acesso em: 17 nov. 2012.

27.

Lei Complementar no 340, de 31 de janeiro de 2007. Altera a Lei Complementar Estadual no 163, de 5 de fevereiro de 1999, dispondo sobre Órgãos e Entes do Poder Executivo do Estado, e dá outras providências. Disponível em: <http://www.gabinetecivil. rn.gov.br/acess/pdf/leicom340-.pdf>. Acesso em: 17 nov. 2012.

28. Lei no 8.086, de 15 de abril de 2002. Cria o Instituto de Gestão das Águas do Estado do Rio Grande do Norte - IGARN, e dá outras providências. Disponível em: <http://www.semarh.rn.gov.br/>. Acesso em: 10nov. 2012.

29. . Lei no 6.908, de 01 de julho de 1996. Dispõe sobre a Política Estadual de Recursos Hídricos, institui o Sistema Integrado de Gestão de Recursos Hídricos e dá outras providências. Disponível em: <http://www.semarh.rn.gov.br/>. Acesso em: 20nov. 2012.

30.

Resolução Conjunta CONERH/CONEMA no 01, de 21 de fevereiro de 2008. Estabelece diretrizes de articulação dos procedimentos para obtenção da outorga de direito de uso de recursos hídricos e da licença ambiental. Disponível em: <http://www.idema.rn.gov.br/contentproducao/aplicacao/idema/entidades_ambientais/ gerados/conema_atos_normativos.asp>. Acesso em: 21 nov. 2012.

31. SECRETARIA DE ESTADO DE MEIO AMBIENTE E DOS RECURSOS HÍDRICOS (SEMARH). Plano Estadual de Recursos Hídricos. (relatório síntese) Disponível em: <http://www.semarh.rn. 
gov.br/contentproducao/aplicacao/semarh/sistemadeinformacoes/consulta/detalhe.asp? IdPublicacao=373/>. Acesso em: 20 nov. 2012.

32. . Programa de outorgas e licenças. Disponível em: <http://www.semarh.rn.gov.br/ contentproducao/aplicacao/semarh/programas/gerados/programadeoutorgaselicencas.asp>. Acesso em: 20 nov. 2012.

33. Programa de incentivo à criação de associação de usuários de água. Disponível em: <http://www.semarh.rn.gov.br/contentproducao/aplicacao/semarh/programas/gerados/ programadeincentivoacriacao.asp>. Acesso em: 20 nov. 2012.

34. SOUSA JÚNIOR, W. C. de. Gestão das águas no Brasil: reflexões, diagnósticos e desafios. São Paulo: Peirópolis, 2004. 164 p.

35. TUCCI, C.E. M. et al. Gestão da Água no Brasil. Brasília: UNESCO, 2001. $156 p$. 